Biol. Stud. 2015: 9(3-4); 169-174 • DOI: https://doi.org/10.30970/sbi.0903.219

www.http://publications.Inu.edu.ua/journals/index.php/biology

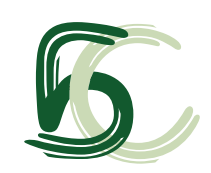

UDC 582.998.1-19(292.452)

\title{
CIRSIUM HETEROPHYLLUM (L.) HILL (ASTERACEAE) IN THE CARPATHIAN MOUNTAINS OF UKRAINE
}

\section{I. Chorney, A. I. Tokaryuk, V. V. Budzhak}

Yuriy Fedkovych Chernivtsi National University, 11, Fedkovych St., Chernivtsi 58022, Ukraine e-mail: chorney.bot@mail.ru

Coenotic peculiarities of the Cirsium heterophyllum (L.) Hill. population found in the Carpathian Mountains of Ukraine have been presented. The community of $C$. heterophyllum is located within the National Nature Park "Verkhovynskyi" on Mt. Gnetesa and occupies an area of about $40 \mathrm{sq}$. meters. It is distributed on the slope of south-eastern exposition with inclination of $15^{\circ}$ and located on the altitude of $1,600 \mathrm{~m}$ above sea level. Total cover of community is $100 \%, C$. heterophyllum is dominant and its cover is $90-$ $95 \%$. There are 19 species growing in the studied community. The community with participation of the $C$. heterophyllum occupies a small area, borders with coenosis of the Hyperico alpigeni-Calamagrostietum villosae Pawł. et Wal. 1949 association of the Calamagrostion villosae Pawł. 1928 alliance, Calamagrostietalia villosae Pawł. 1928 order, Mulgedio-Aconitetea Hadač et Klika in Klika and Hadač 1944 class and is distributed along the upper border of the forest. At present, this is the only known habitat of this species in the Carpathian Mountains of Ukraine. The revealed population of $C$. heterophyllum belongs to the category of small isolated populations. Thus, the constant monitoring of its state and, possibly, active protective measures are required in case of negative dynamic tendencies caused by demutational changes in a vegetative cover at the habitat.

Keywords: Cirsium heterophyllum, coenotic peculiarities, distribution, the Carpathian Mountains of Ukraine.

\section{INTRODUCTION}

Cirsium heterophyllum (L.) Hill. is a native plant species for Europe and Asia. The distribution area of the species expands from the British Islands via Scandinavia, Eastern Europe, Siberia to Altai and north of Mongolia. It being known that in the northeastern Europe it grows mostly in the lowlands, in the south-western direction - in the mountains spreading to mountains of the Mediterranean [4, 23]. It belongs to holarctic element of arctic-alpine sub-element and arctic-alpine-eurosiberian group [24]. As the endangered species $C$. heterophyllum is under protection at the territory of the Republic of Belarus [18] and as a low-risk taxon it is included into the Red Book of the Carpathian Mountains of Poland [4].

ISSN 1996-4536 (print) • ISSN 2311-0783 (on-line) • Біологічні Студії / Studia Biologica • 2015 • Том 9/№3-4 • C. 169-174 
This species is rare for the territory of Ukraine and is located on the left-bank Polissia and Forest-Steppe $[10,20]$. It should be noticed, M.V. Klokov in "Flora of Ukraine" [10] indicates that Ukrainian locations of $C$. heterophyllum, perhaps, are relict. The location of this species in the Carpathian Mountains of Ukraine was not indicated [19, 21].

\section{MATERIALS AND METHODS}

The object of investigation $-C$. heterophyllum, rare species for the territory of the Ukrainian Carpathians. The subject of investigation - distribution, ecological and coenotic peculiarities of communities with $C$. heterophyllum in their composition.

Distribution of species in region was studied on the basis of materials of Herbariums CHER, KW, LW, LWS, LWKS, UU, literature and the results of our field research. The map of distribution of $C$. heterophyllum was composed by the adapted to the Chernovtsy region grid mapping method used in "Atlas Florae Europaeae..." [1, 2]. Coenotic attachment of $C$. heterophyllum population was determined on the basis of the geobotanical descriptions carried out by the authors in the area of research.

Nomenclature of taxa was presented by S. L. Mosyakin and M. M. Fedoronchuk [12].

\section{RESULTS AND DISCUSSION}

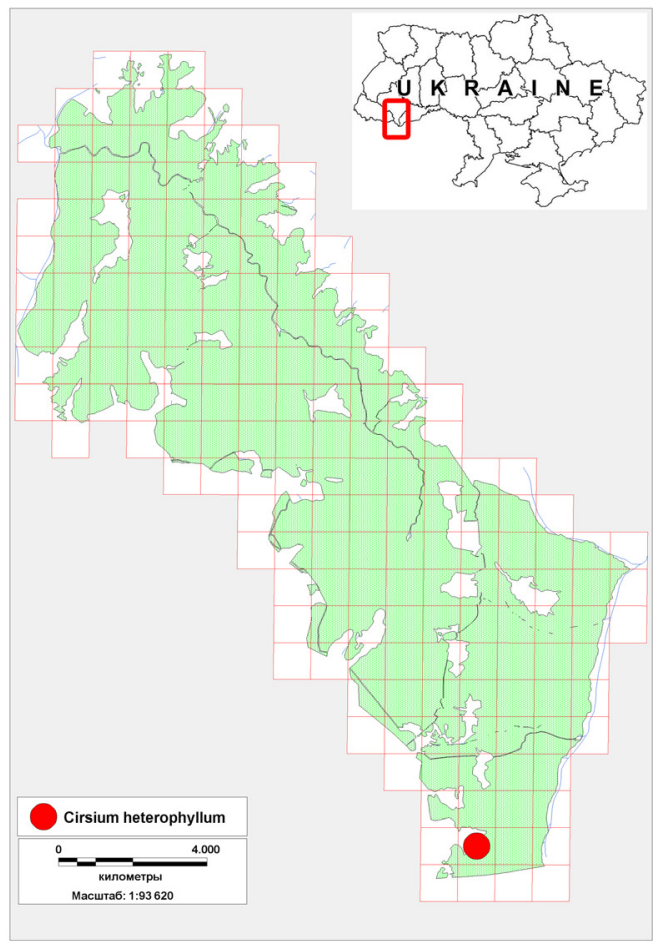

Location of C. heterophyllum (L.) Hill. in the Carpathian Mountains of Ukraine (National Nature Park "Verkhovynskyi")

Місцезнаходження C. heterophyllum (L.) Hill. в Українських Карпатах

(Національний природний парк "Верховинський")
In 2004, during the studies of flora in the Chyvchynski Mountains (Ukrainian Carpathians) a new location of $C$. heterophyllum, as a part of tallgrass communities distributed on the south-eastern slope of the Mt. Gnetesa (approximate altitude $1600 \mathrm{~m}$ above sea level) near the UkraineRomania border, was found (Figure).

C. heterophyllum was included into the third edition of the "Red Data Book of Ukraine" under the nature protection status "insufficiently known" [8]. At that time the indicated locality was the only known species location in Ukraine. In the works by G.O. Klymenko [9] and S.M. Panchenko [14] published throughout next years it was informed about findings of this species on the territory of the National Nature Park "Desniansko-Starogutsky".

Taking into account nature-oriented status of this species in Ukraine and based on our study of specimens of the Herbarium of M.G. Kholodny Institute of Botany NAS of Ukraine $(K W)$ and Yuriy Fedkovych Chernivtsy National University (CHER), the list of the presently known locations of $C$. heterophyllum on the territory of Ukraine is the following (citation by the modern administrative and territorial division of Ukraine). 
1. Kharkiv region, Izium district, suburbs of Lyman station along the railway, near marshes and birch forests to the east from station. June 21, 1920, leg., det. M. Klokov (KW)

2. Kharkiv region, Izium district, Lyman station, outskirts of a forest. June 27, 1929, leg., det. M.Klokov (KW)

3. Kharkiv region, Izium district, village of Spivakivka. June 03, 1843, leg.? September 11, 1929, det. E. Lavrenko (KW)

4. Kharkiv region, Zhykhar-Bezliudivka road. leg. Nalyvaiko, det. E. Lavrenko (KW)

5. Kharkiv region, north-east from Kozenkov. Slopes of gully. August 11, 1932, leg. Efimenko, det. O.Narshyna $(K W)$

6. Sumy region, Seredyno-Budskyi district, village of Kamianka, at the cutting down of timber. June 28, 1953, leg., det. A. Barbarych, O. Barbarych (KW)

7. Sumy region, Seredyno-Burdskyi district, village of Bilousivka, outskirts of a pine forest. June 30, 1998, leg., det. S. Panchenko (KW 004917)

8. Ivano-Frankivsk region, Verhovyna district, Chyvchynski Mountains, Mt. Gnetesa. August 11, 2004, leg., det. I. Chorney, V. Velychko, V. Budzhak, A. Tokaryuk, I. Korotchenko (CHER).

According to the above mentioned data, there are two reliable known localities of this species out of eight locations in Ukraine. One of them spreads on the territory of more than several hundreds sq. meters and is located in National Nature Park "Desniansko-Starogutsky" [14].

The founded group of $C$. heterophyllum is located within the National Nature Park "Verkhovynskyi" on Mt. Gnetesa and occupies area of about 40 sq. meters. It is distributed on the slope of south-eastern exposition with inclination of $15^{\circ}$ and located on the altitude of $1,600 \mathrm{~m}$ above sea level. Total cover of community is $100 \%$, C. heterophyllum is dominant and its cover is $90-95 \%$. There are 19 species growing in the studied community. Knautia maxima (Opiz) Ortman and Lathyrus pratensis L. cover is 1-5\%. Achillea carpatica Błocki ex Dubovik, Aposeris foetida (L.) Less., Bistorta officinalis Delarbre, Carex pallescens L., Centaurea phrygia L., Deschampsia cespitosa (L.) P. Beauv., Geranium alpestre Schur, Hypericum maculatum Crantz, Luzula luzuloides (Lam.) Dandy and Wilmott, Luzula sylvatica (Huds.) Gaudin, Potentilla erecta (L.) Raeusch., Ranunculus lanuginosus L., Rhinanthus pulcher Günther et Schummel ex Opiz subsp.alpinus (Walp.) Rauschert, Scorzonera rosea Waldst. et Kit., Solidago alpestris Waldst. et Kit. ex Willd., Veratrum album L. have cover "r" or "+".

Due to the absence of appropriate number of data, we were not able to find out its syntaxonomical assigning. However, similar communities with similar complex of species are described in Czech Republic and included into the Polygono bistortae-Cirsietum heterophylli Balátová-Tuláčková 1975 association, Calthion palustris Tx. 1937 alliance, Molinietalia caeruleae W.Koch 1926 order, Molino-Arrhenatheretea R.Tx. 1937 class [3].

The community with participation of the $C$. heterophyllum occupies a small area, borders with coenosis of the Hyperico alpigeni-Calamagrostietum villosae Pawł. et Wal. 1949 association of the Calamagrostion villosae Pawł. 1928 alliance, Calamagrostietalia villosae Pawł. 1928 order, Mulgedio-Aconitetea Hadač et Klika in Klika and Hadač 1944 class and is distributed along the upper border of the forest. Up the slope (distance is about 20 meters) there is an insular spruce forest of the Piceion excelsae Pawłowski et al. 1928 alliance, Piceetalia excelsae Pawłowski et al. 1928 order, Vaccinio-Piceetea Br.-BI. in Br.-Bl. et al. 1939 class, that is a part of habitat 9410 Acidophilous Picea forests of the

ISSN 1996-4536 (print) • ISSN 2311-0783 (on-line) • Біологічні Студії / Studia Biologica • 2015 • Том 9/№3-4 • С. 169-174 
montane to alpine levels (Vaccinio-Piceetea) (Natura 2000) [17]. Rarefied wood layer with well-developed grass cover which could contain $C$. heterophyllum that belongs to the category of forest-meadow species is specific to the species habitat [5-7, 11, 13, 22].

It should be noted that this territory was studied in detail by the Polish botanists in the 30-ies of the last century. Locality of the $C$. heterophyllum is nearby Mt. Fatia-Banuluia (about $500 \mathrm{~m}$ ), where the vegetation cover was inspected more than once $[15,16$, 25], but the population of this tallgrass species with bright flowers was not noticed by them. Perhaps, at that time C. heterophyllum grew in a spruce forest.

At the Soviet Union time, at the foot of the Mt. Gnetesa there was a mountain pasture ground farm and a part of the forest was cut down for its expansion. Probably, that became the reason why this population appeared in an open place. At present the grazing has stopped and demutational changes in the vegetation cover are taking place, so it leads to the gradual afforestation. As a result, a part of population that grows beneath the pine trees (7-10 $\mathrm{m}$ height) has increased.

According to our monitoring, due to the vegetative propagation thickness and expansion of this population area takes place in the Chyvchynski Mountains. In 2004, its area was 30 sq. meters, in $2012-40$ sq. meters. Cover of the species is increasing: it was $70-80 \%$ in 2004, and 90-95\% in 2012.

\section{CONCLUSIONS}

C. heterophyllum is forming an isolated small in number population on a small area in Chyvchynski Mountains and is distributed in a specific habitat that is in the process of demutanional changes. At present, this is the only known location of this species in the Carpathian Mountains of Ukraine. The revealed population of $C$. heterophyllum belongs to a category of small isolated populations. Thus, constant monitoring of its state and, possibly, active protective measures are required in case of negative dynamic tendencies caused by demutational changes in vegetative cover at the habitat.

1. Atlas Florae Europaeae: Distribution of vascular plants in Europe / ed. J. Jalas, J. Suominen; On the basis of team-work of European botanist. 1. Pteriodophyta (Psilotaceae to Azollaceae). Helsinki, 1972. $121 \mathrm{p}$.

2. Budzhak V.V., Chorney I.I., Tokaryuk A.I. Supplement to the method of flora species mapping (Chernivtsy district example). Scientific Herald of Chernivtsy University. Biology, 2009: 455; 168-170.

3. Chytrý M. (Ed). Vegetace České Republiky. 1. Travinná a keříčková vegetace. Praha: Academia, 2007. 525 p.

4. Czerwona Księga Karpat Polskich. Rośliny naczyniowe / red. Zbigniew Mirek, Halina Piękoś-Mirkowa. Kraków, 2008. 615 s.

5. Ershova E.A. Anthropogenic transformation in natural communities in the stand with the participation of bracken fern (Pteridium pinetorum). The Flora of Asian Russia, 2012; 2(10): 132-138. (In Russian).

6. Fedorov E.N., Pervushin V.A. The dynamics of the biodiversity of ground cover forests of southern and northern taiga of Central Siberia. Forest Science, 2004; 3: 51-56. (In Russian).

7. Ivanova N.S., Bystrai G.P. The model of formation of the structure of the tree layer in clearings. Part 1: The control parameters. Agrarian Herald Urals, 2010; 5(71): 85-89. (In Russian).

8. Kagalo A.A., Chornei I.I. Cirsium heterophyllum (L.) Hill. Red Data Book of Ukraine. World of Plants / ed. Y.P. Didukh. Kyiv: Hlobalkonsaltynh, 2009. P. 316. (In Ukrainian).

9. Klokov N.V. Rhode 914. Sow thistle - Cirsium Adans. Flora of the USSR. Kyiv: Publishing House of the USSR Academy of Sciences, 1962; 1: 525-548. (In Ukrainian).

ISSN 1996-4536 (print) • ISSN 2311-0783 (on-line) • Біологічні Студії / Studia Biologica • $2015 \bullet$ Том 9/№3-4 • C. 169-174 
10. Klymenko G.O. Rare species of vascular plants of Ukrainian Polissia and some of its territories. Official Bulletin. A series of "Agriculture and Biology", 2010; 4(19): 25-28. (In Ukrainian).

11. Korobeinikova V.P. The impact of anthropogenic factors on forest meadows Ilmensky reserve. Bulletin of the Chelyabinsk Scientific Center, 2002; 2(15): 79-84. (In Russian).

12. Mosyakin S.L., Fedoronchuk M.M. Vascular plants of Ukraine. A nomenclatural checklist. Kyiv, 1999. $346 \mathrm{p}$.

13. Ovesnov S.A., Efimchik E.G., Pleshivikch N.V. Flora and vegetation of protected area "Kvarkush". Bulletin of Udmurt University, 2010: 4; 74-85. (In Russian).

14. Panchenko S.N. National Nature Park "Desniansko-Starogutsky". Biodiversity of nature reserves and national parks of Ukraine. Part 2. National parks / team of authors, ed. V.A. Onishchenko, T.L. Andrienko. Kyiv: Fitosotsiotsentr, 2012. P. 215-229. (In Ukrainian).

15. Pawłowski B. Ogólna charakterystyka geobotaniczna Gór Czywczyńskich. Rozpr. Wydz. Mat.-Przyr. Pol. Akad. Umiejętn, Krakow, 1948. P. 1-72.

16. Pawłowski B., Walas J. Les associations des plantes vesculaires des Monts de Czywczyn. Bull. Acad. Pol. Sc, Ser. B, Sci.-Nat, 1949: 1-181.

17. Prots $B$., Kagalo A. (Eds) Catalogue of habitat types of the Ukrainian Carpathians and Transcarpathian Lowland. Lviv: Mercator, 2012. 294 p. (In Ukrainian).

18. Red Data Book of the Republic of Belarus: Rare and endangered species of wild plants. Minsk: Belarusian Entsyklapedyya, 2006. 456 p. (In Russian).

19. Tasenkevitsh L. Flora of the Carpathians. Checklist of the native vascular plant species. Lviv: State Museum of Natural History, 1998. 610 p.

20. The determinant of higher plants of Ukraine / ed. D.M. Dobrochaeva, M.M. Kotova, Yu. Prokudin et al. - Kiev: Naukova Dumka, 1999. 545 p. (In Russian).

21. The determinant plant Ukrainian Carpathians / ed. V.I. Chopik. - Kyiv: Naukova Dumka, 1977. 434 p. (In Ukrainian).

22. Torchik S.P., Titok V.V. Features of development and seed breeding of some rare and endangered plants of the natural flora of Belarus in terms of culture. Bulletin of the National Academy of Sciences of Belarus. Series of Biological Sciences, 2013; 3; 23-27. (In Russian).

23. Tsvelev N.N. Thistle - Cirsium Mill. Flora of the European part of the USSR / ed. N.N. Tsvelev. SPb.: Science, 1994. Vol. 7. P. 235-247. (In Russian).

24. Zając M., Zając A. The geographical elements of native flora of Poland. Krakow, 2009. 94 p.

25. Zapałowicz H. Roślinna szata gór Pokucko-Marmaroskich. Kraków. Spraw. Kom. Fizjograf, 1889; 24: 389.

\section{CIRSIUM HETEROPHYLLUM (L.) HILL (ASTERACEAE) В УКРАЇНСЬКИХ КАРПАТАХ}

I. І. Чорней, А. І. Токарюк, В. В. Буджак

Чернівецький національний університет імені Юрія Федьковича вул. Федьковича, 11, Чернівці 58022, Україна e-mail: chorney.bot@mail.ru

Наведено ценотичну характеристику популяції Cirsium heterophyllum (L.) Hill., виявленої в Українських Карпатах. Знайдене нами угруповання за участю C. heterophyllum лежить у межах національного природного парку “Верховинський” на г. Гнєтєса, де займає площу близько 40 м². Воно належить до схилу південно-східної експозиції крутизною $15^{\circ}$ і розташоване на висоті 1600 м н.р.м. Загальне проективне покриття ценозу становить $100 \%$, домінує C. heterophyllum - 90-95\%. У складі дослідженого угруповання росте 19 видів. Угруповання за участю C. heterophyllum

ISSN 1996-4536 (print) • ISSN 2311-0783 (on-line) • Біологічні Студії / Studia Biologica • 2015 • Том 9/№3-4 • С. 169-174 
займає невелику площу, межує з ценозами асоціації Hyperico alpigeni-Calamagrostietum villosae Pawł. et Wal. 1949 союзу Calamagrostion villosae Pawł. 1928 порядку Calamagrostietalia villosae Pawł. 1928 класу Mulgedio-Aconitetea Hadač et Klika in Klika et Hadač 1944 і належить до верхньої межі лісу. Це єдине відоме на сьогодні місцезростання виду в Українських Карпатах. Виявлена популяція C. heterophyllum належить до категорії малих ізольованих популяцій, у зв'язку з чим необхідний постійний контроль за її станом і, можливо, активні заходи охорони у разі появи негативних динамічних тенденцій, пов'язаних із демутаційними змінами рослинного покриву оселища.

Ключові слова: Cirsium heterophyllum, ценотичне місцезростання, Українські Карпати.

\title{
CIRSIUM HETEROPHYLLUM (L.) HILL (ASTERACEAE) В УКРАИНСКИХ КАРПАТАХ
}

\author{
И. И. Чорней, А. И. Токарюк, В. В. Буджак \\ Черновицкий национальный университет имени Юрия Федьковича \\ ул. Федьковича, 11, Черновцы 58022, Украина \\ e-mail: chorney.bot@mail.ru
}

Приведена ценотическая характеристика популяции Cirsium heterophyllum (L.) Hill., обнаруженной в Украинских Карпатах. Найденное нами сообщество с участием C. heterophyllum находится в пределах национального природного парка "Верховинский" на г. Гнетеса, где занимает площадь около 40 м². Оно приурочено к склону юго-восточной экспозиции крутизной $15^{\circ}$ и расположено на высоте 1600 м над уровнем моря. Общее проективное покрытие ценоза составляет $100 \%$, доминирует C. heterophyllum, покрытие которого достигает 90-95 \%. В составе исследованного сообщества произрастает 19 видов. Сообщество с участием C. heterophyllum занимает небольшую площадь, граничит с ценозами ассоциации Нуреrico alpigeni-Calamagrostietum villosae Pawł. et Wal. 1949 союза Calamagrostion villosae Pawł. 1928 порядка Calamagrostietalia villosae Pawł. 1928 класса Mulgedio-Aconitetea Hadač et Klika in Klika et Hadač 1944 и приурочено к верхней границе леса. Это единственное известное на сегодня местопроизрастание вида в Украинских Карпатах. Обнаруженная популяция C. heterophyllum относится к категории малых изолированных популяций, в связи с чем необходим постоянный контроль за ее состоянием и, возможно, активные меры охраны в случае появления негативных динамических тенденций, связанных с демутационными изменениями растительного покрова биотопа.

Ключевые слова: Cirsium heterophyllum, ценотическая приуроченность, Украинские Карпаты.

Одержано: 16.11.2015

ISSN 1996-4536 (print) • ISSN 2311-0783 (on-line) • Біологічні Студії / Studia Biologica • 2015 • Том 9/№3-4 • С. 169-174 